\title{
EFFECT OF SPRAYING WASHINGTON NAVEL ORANGE TREES WITH SELENIUM ON VEGETATIVE GROWTH, PRODUCTIVITY AND FRUIT QUALITY
}

\author{
Bakr $^{1, *}$ B.M., A.A. El-Gazzar ${ }^{2}$, Noha A. Mansour ${ }^{2}$ and M.I. Fawzy ${ }^{1}$
}

2- Horticlture Dept., Fac. of Agric., Ain Shams Univ. P.O. Box 68 Hadayek Shoubra, 11241, Cairo, Egypt

2- Pomology Dept., National Research Centre, Dokki, Giza, Egypt

*Corresponding author: basemlife@yahoo.com

\section{ABSTRACT}

This study was carried out during two successive seasons, 2012 and 2013 in a private orchard in Barshom vallage located at El-Kalubia Governorate Egypt. Washington Navel Orange trees (Citrus Sinensis) budded on sour orange rootstock (Citrus aurantium, L.) were 7- years- old and planted at $5 \times 5$ meters under basin irrigation system. This investigation aimed to study the effect of selenium (Se) levels $(0,20,40,80$ and $160 \mathrm{ppm})$ as foliar spray on growth, yield, fruit quality, leaf mineral content and enzymes activity of Washington Navel orange trees. The obtained data showed that, selenium had a significant promotive effect on growth, yield, fruit quality, leaf mineral content and enzymes activity of Washington Navel orange trees. Results indicated that treatment of Se at 40 ppm gave the highest significant results, whereas, treatment 160 ppm gave the highest fruit selenium content.

Keywords: Washington Navel Orange, Selenium, Yield, Fruit quality, Leaf mineral content

\section{INTRODUCTION}

Citrus is the backbone of fruit crop cultivation in Egypt. It takes the first rank in Egypt and the second after grapes in the world for total fruit among crops production. The cultivated area has grown rapidly in the last two decades and reached 533835 feddans. Washington Navel orange cv. is considered to be one of the important and best orange cv. in Egypt. Total area 179876 feddans. (M.A.L.R., 2015).

Many attempts have been conducted to improve the yield and fruit quality of Washington $\mathrm{Na}$ vel orange trees grown under El-Kalubia Governorate conditions by using new cultural practices especially fertilization with selenium (Sima and Gissel-Neilsen, 1985).

Selenium as an element chemically similar to sulfur has received considerable attention as an essential micronutrient for human, animals and some species of microorganisms. It has many functions in the active site of a large number of selenium dependent enzymes such as glutathioneperoxidase and as anticancer and other physiological functions. A lower selenium level in body is reported to be responsible for high incidence of cancer and disease (Gupta et al 2000). It also influences the nutrient balance in the plants (Nowak- Barbara, 2008).

Selenium (Se) is an important element associated with the enhancement of antioxidant activity in plants, animals and humans (Rayman 2002). [Beneficial effects of Se were appeared in terms of plant protection against abiotic stress (Hartikainen and Xue 1999)] plant protection against reactive oxygen compounds, activator of the protective mechanism that reduces oxidation stress for example in chloroplasts (Seppanen et al 2003), phloem-feeding aphids and herbivorous caterpillars and fungal diseases (Hanson et al 2003). Selenium has a positive effect also on potato carbohydrate accumulation and possibly on yield formation (Turakainen et al 2004 and 2006). 
Spraying Se-fertilizer to leaves is a sound method for supplementing selenium to the strawberries and a suitable amount of selenium can alleviate the toxic action to the strawberry caused by heavy metal (Zhang et al 2011).

Thus, the aim of this investigation was examining the beneficial effects of using selenium as (foliar spray) on vegetative growth, leaf mineral content, fruit set, fruit drop, yield and fruit quality of Washington Navel orange trees grown under ElKalubia condition.

\section{MATERIALS AND METHODS}

This study was carried out during two successive seasons, 2012 and 2013 on 7-years old Washington Navel Orange Trees (Citrus Sinensis) budded on sour orange rootstock (Citrus aurantium, L.) and planted at $5 \times 5$ meters under basin irrigation system. Healthy, nearly uniform tree in growth vigor and fruiting were chosen. The trees are grown in a private orchard in Barshom vallage located at El-Kalubia Governorate Egypt. The texture of the tested soil is loam. Physical and chemical properties of the soil at a depth of $(0.0$ $30 \mathrm{~cm})$ and $(30-60 \mathrm{~cm})$ were determined according to Wilde et al (1985) and data are shown in Table (1).

Table 1. Physical and chemical analyses of the experimental soil

\begin{tabular}{|c|c|c|c|c|c|c|c|c|}
\hline \multicolumn{9}{|c|}{ Physical analysis } \\
\hline Soil depth & $\begin{array}{c}\text { Sand } \\
\%\end{array}$ & $\begin{array}{c}\text { Silt } \\
\%\end{array}$ & $\begin{array}{c}\text { Clay } \\
\%\end{array}$ & Texture & $\mathrm{pH}$ & $\mathrm{EC}(\mathrm{ds} / \mathrm{m})$ & $\begin{array}{c}\mathrm{CaCO}_{3} \\
\%\end{array}$ & $\begin{array}{c}\text { Organic matter } \\
\%\end{array}$ \\
\hline $0-30 \mathrm{~cm}$ & 10.8 & 44 & 45.2 & Loam & 8.4 & 0.5 & 1.2 & 1.6 \\
\hline $30-60 \mathrm{~cm}$ & 12.8 & 44 & $43 . .2$ & Loam & $8 . .4$ & 0.4 & 2 & 1.1 \\
\hline \multicolumn{9}{|c|}{ Chemical analysis } \\
\hline Soil depth & $\mathrm{N} \%$ & $\mathbf{P} \%$ & K \% & $\mathrm{Ca} \%$ & $M g \%$ & Fe ppm & Zn ppm & Mn ppm \\
\hline $0-30 \mathrm{~cm}$ & 0.13 & 0.6 & 0.9 & 4.2 & 1.1 & 7.8 & 3.4 & 3.2 \\
\hline $30-60 \mathrm{~cm}$ & 0.10 & 0.6 & 0.6 & 3.4 & 0.9 & 5.5 & 2.4 & 1.8 \\
\hline
\end{tabular}

The study involved five levels of selenium (Se). Thus the experiment was laid out as a simple experiment arranged with four replicates in a randomized complete block design and each replicate was represented by one tree. Regarding selenium treatments, selected trees were sprayed two times during the season the first at the first week of Mar. and the second at the first week of Sept. By the aqueous solution of sodium selenite (20\% Se) $\left(\mathrm{Na}_{2} \mathrm{SeO}_{3}, 5 \mathrm{H}_{2} \mathrm{O}\right)$. and spraying was done until the point of runoff $(20 \mathrm{~L} /$ tree $)$. with the different selenium concentrations: $(0-20-40-80-160$ ppm) and Triton $\mathrm{B}$ as a wetting agent was applied at $0.05 \%$ to all spraying solutions. The recommended concentrations according to (Jakovljevic et al. 2011). Control trees were sprayed with tap water and Triton B.

Organic manure was added in the first week of January whereas mineral nitrogen as ammonium sulphate $(20.6 \% \mathrm{~N})$ was added at three equal batches in the first week of March, May and August. Other horticultural practices were carried out as usual.
The effect of different Se concentrations on vegetative growth, yield, fruit quality, and leaf mineral content of the spring growth cycle in the two studied seasons was investigated as follows:

\section{Parameters}

\section{1- Vegetative growth parameters}

The spring flush growth cycle on 20 secondary branches in the mid of May in both seasons were determined.

\section{a. Shoot Number, Shoot Length (cm) and Leaf number/ shoot}

At the last week of May the number and length of new full developed spring growth cycle shoots on 20 secondary branches were measured, also the number of leaves on such shoots were recorded. 


\section{b. Leaf area $\left(\mathrm{cm}^{2}\right)$.}

Leaf area of 40 mature leaves at different four sides of each tree was calculated using the equation of Ahmed and Morsy, (1999) where: Leaf area $=0.46$ (length $\mathrm{x}$ width) +19.09 .

\section{2- Fruit set percentage}

and the results were estimated as follows.

$$
\text { Fruit set }(\%)=\frac{\text { No. of fruitlets }}{\text { No. of flowers }} \times 100
$$

These data were recorded every two weeks from first of many to $15^{\text {th }}$ of December in both seasons.

\section{3- Yield}

At harvest time, when color break under the experimental conditions (the mid of December), the yield expressed as weight $(\mathrm{Kg})$ and number of fruits per tree was recorded.

\section{4- Fruit physical characteristics}

Then a random sample of fruits (20 fruits from each tree) was picked to determine some physical and chemical properties as average fruit weight $(\mathrm{g})$, fruit volume $(\mathrm{ml})$, fruit height $(\mathrm{cm})$, fruit diameter $(\mathrm{cm})$, peel thickness $(\mathrm{cm})$, pulp weight $(\mathrm{g})$ and pulp \%.

Pulp \%: was calculated according to the following equation:

$$
\text { Pulp \% }=\frac{\text { Pulp weight }}{\text { Fruit weight }} \times 100
$$

\section{5- Fruit chemical characteristics}

Then, S.S.C. \%, titratable acidity \%, S.S.C. / acid ratio and $\mathrm{L}$. ascorbic acid were determined in fruit juice according to the methods outlined in A.O.A.C. (1995).

\section{6- Leaf mineral content}

Sample of 50 mature leaves of 7 month old from non fruiting and non flushing shoots from the spring growth cycle were selected according to Nijjar (1985) and taken at random in the 1st week of September. Jones \& Embleton (1969).
Nitrogen (\%) was determined by using modified MicroKjeldahl procedure according to Pregl (1945). P (\%) was estimated as described by Chapman \& Pratt (1961). K (\%) was determined by using a Flamephotometer according to the method of Brown \& Lilleland (1946). Ca (\%), Mg (\%), Fe, Zn, Mn and Se (ppm) were determined by using Perkin Elmer Atomic absorption spectrophotometer Model 305 B (Piper, 1958).

\section{6- Fruits selenium content (ppm)}

Random sample of pulp fruits (20 pulp fruits from each tree) was picked to determine selenium (Piper, 1958).

\section{7- Enzymes activity}

In the second season, two times as in the first mid May and in the second at mid December, the sample of 20 neck of fruits were determind each of:

a- Cellulase activity: was determined according to (Durbin and Lewis, 1988)

b- Pectinase activity: was determined according to (Durbin and Lewis, 1988) and (Abeles and Takeda, 1990).

All the obtained data were tabulated and statistically analysed according to Snedecor \& Cochran (1980). The means were separated by Duncan's multiple range test Duncan (1955).

\section{RESULTS AND DISCUSSION}

\section{1-Vegetative growth parameters}

Data in Table (2) showed the effect of selenium on some vegetative growth parameters as follows:

\section{a- Shoot number}

The highest values were obtained by spraying trees with 20 and 160 ppm selenium in the first and second seasons, respectively. Followed closely without any significant difference by $40,80,160$ ppm in the first season and 20ppm in the second season, on the other hand control gave the lowest significant values in the two seasons. 
b- Soot length(cm): The highest values resulted from the control $(14.9 \& 15.4 \mathrm{~cm})$ in both seasons, followed by spraying trees with $80 \mathrm{ppm}$ selenium $(14.0 \& 14.2 \mathrm{~cm})$ in both seasons, without any significant differences between them. On the other hand, spraying trees with $160 \mathrm{ppm}$ selenium gave the lowest values $(7.6 \& 7.7 \mathrm{~cm})$ in the two seasons. The other treatments recorded intermediate values.

c- Number of leaves /shoot: Spraying selenium at $80 \mathrm{ppm}$ gave the highest values (11.3 \& 14.2) in both seasons. While, the lowest values was resulted from the control which recorded 6.0 \& 7.7 in both seasons, respectively. Other treatments gave in between results. d- Leaf area $\left(\mathrm{cm}^{2}\right)$ : Control treatment gave the highest values of leaf area which recorded 37.0 \& $37.8 \mathrm{~cm}^{2}$ in both seasons, respectively, followed by spraying trees with $80 \mathrm{ppm}$ selenium which recorded $36.5 \& 34.6 \mathrm{~cm}^{2}$ in both seasons. However, the lowest values resulted from spraying trees with 160 ppm selenium $28.3 \& 24.5 \mathrm{~cm}^{2}$ in both seasons, respectively.

These results are in harmony with those found by Ya-o-Xiang and Zheng-Fo (2007) and Ibrahim and Al- Wasfy, (2014) on orange trees who mentioned that, the selenium is one kind of extremely important trace element in ecological environment, it has the important physiological function in the plant and effectively enhanced growth characters.

Table 2. Effect of selenium spraying on some vegetative growth parameters of Washington Navel orange trees in 2012 \& 2013 seasons

\begin{tabular}{|l|c|c|c|c|c|c|c|c|}
\hline \multirow{2}{*}{ Growth parameters } & \multicolumn{7}{|c|}{ Spring flush growth } \\
\cline { 2 - 8 } & $\begin{array}{c}\text { Shoot Number/ } \\
\text { secondary shoots }\end{array}$ & $\begin{array}{c}\text { Shoot Length } \\
\text { (cm) }\end{array}$ & $\begin{array}{c}\text { Number of } \\
\text { leaves/shoot }\end{array}$ & \multicolumn{2}{c|}{$\begin{array}{c}\text { Leaf area } \\
\left(\mathbf{c m}^{2}\right)\end{array}$} \\
\cline { 2 - 9 } Treatments & $\mathbf{2 0 1 2}$ & $\mathbf{2 0 1 3}$ & $\mathbf{2 0 1 2}$ & $\mathbf{2 0 1 3}$ & $\mathbf{2 0 1 2}$ & $\mathbf{2 0 1 3}$ & $\mathbf{2 0 1 2}$ & $\mathbf{2 0 1 3}$ \\
\hline T1-control (Tap water spray). & $5.8 \mathrm{~b}$ & $5.4 \mathrm{c}$ & $14.9 \mathrm{a}$ & $15.4 \mathrm{a}$ & $6.0 \mathrm{c}$ & $7.7 \mathrm{~d}$ & $37.0 \mathrm{a}$ & $37.8 \mathrm{a}$ \\
T2- 20ppm selenium. & $8.1 \mathrm{a}$ & $7.8 \mathrm{ab}$ & $12.5 \mathrm{ab}$ & $12.7 \mathrm{dc}$ & $8.1 \mathrm{~b}$ & $12.7 \mathrm{bc}$ & $34.3 \mathrm{ab}$ & $28.5 \mathrm{~b}$ \\
T3- 40ppm selenium. & $7.0 \mathrm{ab}$ & $7.1 \mathrm{~b}$ & $10.6 \mathrm{~b}$ & $10.8 \mathrm{c}$ & $7.8 \mathrm{bc}$ & $10.8 \mathrm{c}$ & $31.3 \mathrm{bc}$ & $36.7 \mathrm{a}$ \\
T4- 80ppm selenium. & $7.0 \mathrm{ab}$ & $7.0 \mathrm{~b}$ & $14.0 \mathrm{a}$ & $14.2 \mathrm{ab}$ & $11.3 \mathrm{a}$ & $14.2 \mathrm{ab}$ & $36.5 \mathrm{a}$ & $34.6 \mathrm{a}$ \\
T5- 160ppm selenium. & $7.1 \mathrm{ab}$ & $9.0 \mathrm{a}$ & $7.6 \mathrm{c}$ & $7.7 \mathrm{~d}$ & $9.0 \mathrm{~b}$ & $15.4 \mathrm{a}$ & $28.3 \mathrm{c}$ & $24.5 \mathrm{~b}$ \\
\hline
\end{tabular}

Means having the same letter(s) within a column are not significantly different at $5 \%$ level

\section{2- Fruit set}

a- Initial fruit set \%: Data presented in Table (3) indicated insignificant differences among treatments in the first date. However, spraying trees with 160 ppm selenium gave the slightly increase initial fruit set \% (79.5) in the first season but in the second seasons, spraying trees with 20 ppm selenium gave the slightly increase initial fruit set \% (82.2). On the contrary, control gave the lowest values in this respect, (76.3 \& 76.2) in both seasons.

b- Retained fruits \%: concerning to fruit set at different dates through both growing seasons. In the first season from $15 / 5 / 2012$ to $1 / 12 / 2012$ data revealed that most recorded data had insignificant differences among treatment. In some cases such as $15 / 6$ and $1 / 7$ control treatment showed lowest significant fruit set percentage. In the second sea- son, control treatment recorded lowest significant values at $15 / 10,15 / 11$ and 1/12/2013.

c- Final retained fruits \%: Data indicated that all Se concentrations gave higher significant values of final retained fruits than the control treatment in both seasons.

\section{3- Yield}

Tow yield measurements evaluated were estimated as weight $(\mathrm{kg})$ and number of harvested fruits per tree. Table (4) showed that all selenium spray treatments increased significantly tree yield (either $\mathrm{kg}$, number of harvested fruits or fruit weight) than control. However, selenium spray at $40 \mathrm{ppm}$ tended to be more effective as yield was recorded as weight of fruits/tree 92.8 \& 80.3 $\mathrm{kg} / \mathrm{tree}$, while $160 \mathrm{ppm}$ concentration was the superior (312.9 \& 292.9) fruits per tree during the first and the second seasons, respectively. 


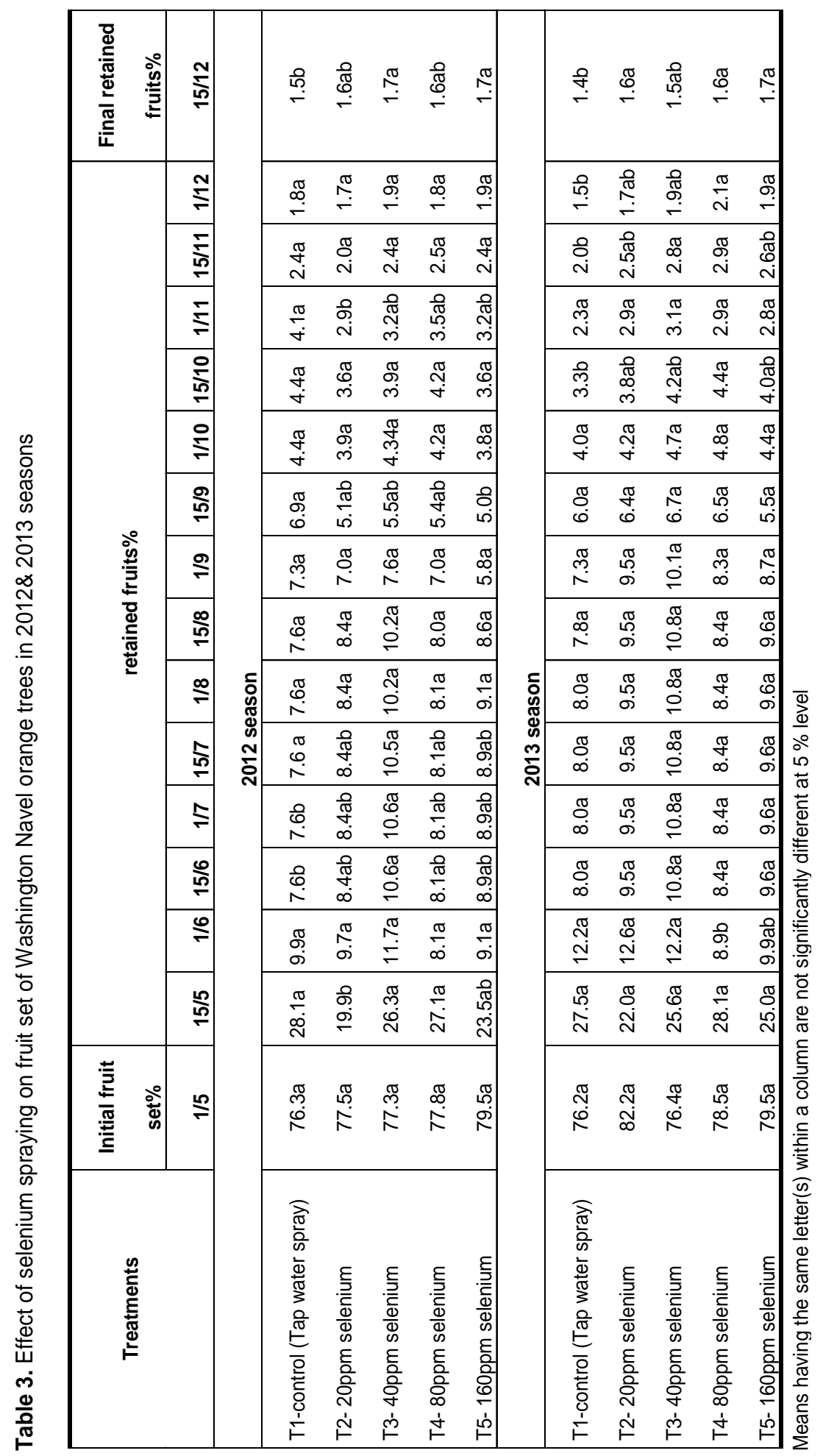


Table 4. Effect of selenium spraying on yield of Washington Navel orange trees in $2012 \& 2013$ seasons

\begin{tabular}{|l|c|c|c|c|c|c|}
\hline \multirow{2}{*}{\multicolumn{1}{c|}{ Treatments }} & \multicolumn{2}{|c|}{ Yield (Kg)/tree } & Number of fruits/tree & \multicolumn{2}{c|}{ Fruit weight (g) } \\
\cline { 2 - 7 } & $\mathbf{2 0 1 2}$ & $\mathbf{2 0 1 3}$ & $\mathbf{2 0 1 2}$ & $\mathbf{2 0 1 3}$ & $\mathbf{2 0 1 2}$ & $\mathbf{2 0 1 3}$ \\
\hline T1-control (Tap water spray) & $47.2 \mathrm{c}$ & $46.8 \mathrm{c}$ & $210.6 \mathrm{c}$ & $205.5 \mathrm{c}$ & $224.3 \mathrm{bc}$ & $228.2 \mathrm{~b}$ \\
T2- 20ppm selenium & $75.0 \mathrm{ab}$ & $64.8 \mathrm{~b}$ & $267.4 \mathrm{~b}$ & $237.9 \mathrm{bc}$ & $280.5 \mathrm{ab}$ & $272.7 \mathrm{a}$ \\
T3- 40ppm selenium & $92.8 \mathrm{a}$ & $80.3 \mathrm{a}$ & $286.8 \mathrm{ab}$ & $265.2 \mathrm{ab}$ & $323.9 \mathrm{a}$ & $302.8 \mathrm{a}$ \\
T4- 80ppm selenium & $74.0 \mathrm{ab}$ & $70.9 \mathrm{ab}$ & $269.5 \mathrm{~b}$ & $257.8 \mathrm{ab}$ & $274.8 \mathrm{ab}$ & $275.4 \mathrm{a}$ \\
T5- 160ppm selenium & $66.7 \mathrm{~b}$ & $78.4 \mathrm{ab}$ & $312.9 \mathrm{a}$ & $292.9 \mathrm{a}$ & $213.2 \mathrm{c}$ & $267.7 \mathrm{ab}$ \\
\hline
\end{tabular}

Means having the same letter(s) within a column are not significantly different at $5 \%$ level

In regard to the effect of their treatments on number of fruits per tree and fruit weight, data presented in Table (7) showed that all treatments significant increased number of fruits per tree and fruit weight than untreated trees.

The increment in yield attributed to selenium spraying application may be due to it effect in increasing the fruit volume and weight. These findings are in agreement with those obtained by Gad El-Kareem et al (2014), on zaghlol date palm and Shaimaa et al (2016), on mango trees, who reported that selenium applications gave the highest yield/tree and fruit weight.

\section{4- Fruit Physical characteristics}

Results of various fruit characteristics i.e. (fruit volume, fruit height, fruit diameter, peel thicken, peel weight, pulp weight and pulp\%) as affected by different studied treatments are presented in Table (5) for the two seasons 2012 and 2013.

a- Fruit volume(ml): Was not affected significantly by Se treatments in both seasons.

b- Fruit height $(\mathbf{c m})$ : Results proved that, fruit height was gradually increased by increasing Se up to $40 \mathrm{ppm}$ which gave the highest values.

c- Fruit diameter (cm): Results proved that, fruit diameter was gradually increased by increasing Se up to $40 \mathrm{ppm}$ which gave the highest values.

d- Peel thickness (cm): It is clear from the obtained data that spraying trees with $40 \mathrm{ppm}$ and 80 ppm selenium gave the highest peel thicken (0.5\&0.5) in the first season but in the second seasons, insignificant differences could be noticed among treatments. e- Pulp weight (g): The results of two seasons clearly indicated that pulp weight was more or less similar for most treatments and insignificant between them.

f- Pulp (\%): Data showed insignificant differences among treatments in both seasons.

These data go in line with those reported by Ibrahim and Al-Wasfy (2014) who found that using selenium effectively enhanced physical characteristics of Valencia orange fruits under Minia region conditions and Shaimaa et al (2016). Who revealed that, treatment of $S e$ at 5 ppm gave the highest fruit weight of mango trees.

\section{5- Fruit chemical characteristics}

Resultes in Table (6) show the effect of Se levels on Fruit chemical characteristics.

a- Soluble Solids content (\%): The results revealed that, the lowest significant values of soluble solids content were obtained by control treatment in the two seasons. Other treatment gave more or lesssimilar values with the same statistical stand point.

b- Titreatable acidity (\%): Results indicated that there was no significant difference between all selenium treatments in both seasons.

SSC/acid ratio: Data presented in the same table that there was no significant difference between all selenium treatments in both seasons.

C- L. ascorbic acid(mg/100ml juice): It is clear from the obtained data that there was no significant differences between all selenium treatments in the first season only, but in the second season spraying trees with $20 \mathrm{ppm}$ and $80 \mathrm{ppm}$ selenium proved to be the higher significant values than the control and 60ppm selenium. 
Table 5. Effect of selenium spraying on some fruits physical characteristics of Washington Navel orange trees in $2012 \& 2013$ seasons

\begin{tabular}{|l|c|c|c|c|c|c|}
\hline \multicolumn{1}{|c|}{ Treatments } & $\begin{array}{c}\text { Fruit } \\
\text { volume } \\
\text { (ml) }\end{array}$ & $\begin{array}{c}\text { Fruit } \\
\text { height } \\
\text { (cm) }\end{array}$ & $\begin{array}{c}\text { Fruit } \\
\text { diameter } \\
\text { (cm) }\end{array}$ & $\begin{array}{c}\text { Peel } \\
\text { thickness } \\
\text { (cm) }\end{array}$ & $\begin{array}{c}\text { Pulp } \\
\text { weight } \\
\text { ( g) }\end{array}$ & $\begin{array}{c}\text { Pulp } \\
\text { ( \%) }\end{array}$ \\
\hline & \multicolumn{7}{|c|}{ 2012 season } \\
\hline T1-control (Tap water spray) & $287.6 \mathrm{a}$ & $7.8 \mathrm{~b}$ & $6.9 \mathrm{~b}$ & $0.4 \mathrm{ab}$ & $185.6 \mathrm{a}$ & $73.5 \mathrm{~b}$ \\
T2- 20ppm selenium. & $339.2 \mathrm{a}$ & $8.3 \mathrm{ab}$ & $7.2 \mathrm{ab}$ & $0.3 \mathrm{~b}$ & $240.1 \mathrm{a}$ & $77.3 \mathrm{ab}$ \\
T3- 40ppm selenium. & $337.7 \mathrm{a}$ & $8.9 \mathrm{a}$ & $7.3 \mathrm{ab}$ & $0.5 \mathrm{a}$ & $237.2 \mathrm{a}$ & $78.1 \mathrm{a}$ \\
T4- 80ppm selenium. & $330.2 \mathrm{a}$ & $8.4 \mathrm{ab}$ & $7.5 \mathrm{a}$ & $0.5 \mathrm{a}$ & $231.6 \mathrm{a}$ & $76.9 \mathrm{ab}$ \\
T5- 160ppm selenium. & $306.5 \mathrm{a}$ & $8.1 \mathrm{~b}$ & $7.4 \mathrm{ab}$ & $0.4 \mathrm{ab}$ & $203.3 \mathrm{a}$ & $75.3 \mathrm{ab}$ \\
\hline & \multicolumn{7}{|c|}{$\mathbf{2 0 1 3}$ season } & & \\
\hline T1-control (Tap water spray) & $278.8 \mathrm{a}$ & $7.8 \mathrm{~b}$ & $6.9 \mathrm{a}$ & $0.4 \mathrm{a}$ & $186.4 \mathrm{a}$ & $73.9 \mathrm{a}$ \\
T2- 20ppm selenium & $306.5 \mathrm{a}$ & $8.2 \mathrm{ab}$ & $7.0 \mathrm{a}$ & $0.4 \mathrm{a}$ & $221.5 \mathrm{a}$ & $75.8 \mathrm{a}$ \\
T3- 40ppm selenium & $280.2 \mathrm{a}$ & $8.6 \mathrm{a}$ & $7.1 \mathrm{a}$ & $0.4 \mathrm{a}$ & $192.1 \mathrm{a}$ & $73.8 \mathrm{a}$ \\
T4- 80ppm selenium & $256.7 \mathrm{a}$ & $8.3 \mathrm{ab}$ & $7.4 \mathrm{a}$ & $0.4 \mathrm{a}$ & $185.7 \mathrm{a}$ & $73.7 \mathrm{a}$ \\
T5- 160ppm selenium & $294.2 \mathrm{a}$ & $8.0 \mathrm{ab}$ & $7.3 \mathrm{a}$ & $0.5 \mathrm{a}$ & $214.8 \mathrm{a}$ & $75.2 \mathrm{a}$ \\
\hline
\end{tabular}

Means having the same letter(s) within a column are not significantly different at $5 \%$ level

These results supported the findings of QiuHui et al (2001), who observed that Vitamin C content of green tea was significantly increased by selenium spraying during the autumn tea-producing season.

As a general trend, the improvement of fruit quality attribute with selenium foliar spray for Washington Navel orange cv. (Table 7) could be due to the beneficial effect of shoot growth, leaf area of these treatments probably provided the developing fruit with a steady supply of photosyntyate.

These results are parallel to those of Ibrahim and Al-Wasfy, (2014) who reported that using selenium enhanced chemical characteristics of the fruits of Valencia orange trees growth under Minia region conditions.

Also, Shaimaa et al (2016), who revealed that, treatment of Se at $5 \mathrm{ppm}$ gave the highest total soluble solids of mango trees.

Table 6. Effect of selenium spraying on some chemical characteristics of Washington Navel orange fruits in $2012 \& 2013$ seasons

\begin{tabular}{|l|c|c|c|c|c|c|c|c|}
\hline \multirow{2}{*}{\multicolumn{1}{|c|}{ Treatments }} & \multicolumn{2}{c|}{$\begin{array}{c}\text { Soluble Solids } \\
\text { content (\%) }\end{array}$} & \multicolumn{2}{c|}{$\begin{array}{c}\text { Titratable } \\
\text { acidity (\%) }\end{array}$} & \multicolumn{2}{c|}{$\begin{array}{c}\text { SSC/acid } \\
\text { ratio }\end{array}$} & \multicolumn{2}{c|}{$\begin{array}{c}\text { L. ascorbic acid } \\
\text { (mg/100ml juice) }\end{array}$} \\
\cline { 2 - 9 } & $\mathbf{2 0 1 2}$ & $\mathbf{2 0 1 3}$ & $\mathbf{2 0 1 2}$ & $\mathbf{2 0 1 3}$ & $\mathbf{2 0 1 2}$ & $\mathbf{2 0 1 3}$ & $\mathbf{2 0 1 2}$ & $\mathbf{2 0 1 3}$ \\
\hline T1-control (Tap water spray) & $12.0 \mathrm{~b}$ & $11.8 \mathrm{~b}$ & $0.8 \mathrm{a}$ & $0.9 \mathrm{a}$ & $14.0 \mathrm{a}$ & $12.9 \mathrm{a}$ & $39.5 \mathrm{a}$ & $38.5 \mathrm{~b}$ \\
T2- 20ppm selenium & $14.4 \mathrm{a}$ & $14.2 \mathrm{a}$ & $0.9 \mathrm{a}$ & $0.9 \mathrm{a}$ & $16.4 \mathrm{a}$ & $16.0 \mathrm{a}$ & $49.8 \mathrm{a}$ & $48.5 \mathrm{a}$ \\
T3- 40ppm selenium & $13.3 \mathrm{a}$ & $13.3 \mathrm{a}$ & $0.7 \mathrm{a}$ & $0.8 \mathrm{a}$ & $17.4 \mathrm{a}$ & $16.2 \mathrm{a}$ & $40.9 \mathrm{a}$ & $41.4 \mathrm{~b}$ \\
T4- 80ppm selenium & $13.7 \mathrm{a}$ & $13.8 \mathrm{a}$ & $0.8 \mathrm{a}$ & $0.9 \mathrm{a}$ & $16.2 \mathrm{a}$ & $15.1 \mathrm{a}$ & $47.4 \mathrm{a}$ & $47.2 \mathrm{a}$ \\
T5- 160ppm selenium & $13.5 \mathrm{a}$ & $13.8 \mathrm{a}$ & $0.8 \mathrm{a}$ & $0.8 \mathrm{a}$ & $16.2 \mathrm{a}$ & $15.7 \mathrm{a}$ & $44.3 \mathrm{a}$ & $43.5 \mathrm{ab}$ \\
\hline
\end{tabular}

Means having the same letter(s) within a column are not significantly different at $5 \%$ level 


\section{6- Leaf mineral content}

Results in Table (7) show the effect of selenium levels on $\mathrm{N}, \mathrm{P}, \mathrm{K}, \mathrm{Ca}$, and $\mathrm{Mg}$ percentage, $\mathrm{Fe}$, $\mathrm{Zn}, \mathrm{Mn}$ and Se ppm in leaves of Navel orange in 2012 and 2013 seasons.

a- Nitrogen percentage: Spraying trees with 80 ppm selenium proved to be the beneficial treatment in the both seasons (2.6 \& 2.7) as compared with the control treatment (2.1 in two seasons).

b- Phosphorus percentage: results indicated that spraying trees with $20 \mathrm{ppm}$ selenium gave the highest phosphorus percentage $(0.30)$ in the first season but in the second seasons, spraying trees with $20 \mathrm{ppm}$ and $160 \mathrm{ppm}$ selenium gained the highest phosphorus percentage $(0.31 \& 0.27)$ on the contrary to the control treatment gave the lowest values $(0.16 \& 0.15)$ in both seasons .

c- Potassium percentage: Data showed that Potassium percentage in the first season, all $\mathrm{Se}$ treatments gave higher significant values compared to control, in the second season spraying trees with $80 \mathrm{ppm}$ selenium showed higher si to be the beneficial treatment in the two seasons (1.7) as compared with the control treatment (1.1 \& 1.3). However, the all treatments showed the higher significant values than control. $k$ percentage recorded the higher values than the optimum levels (Jones and Embleton, 1969).

d- Calcium percentage: Results indicated that significant spraying trees with $40 \mathrm{ppm}$ and 160 ppm selenium in the first season gave the highest calcium percentage (5.2 \& 5.3).In the second seasons, spraying trees with $40 \mathrm{ppm}$ selenium gained the higher significant calcium percentage (5.0) than control treatment and the treatment with 20ppm Se (4.3 \& 4.4).

e- Magnesium percentage: Data showed that spraying trees with $40 \mathrm{ppm}$ selenium proved to be the highest increased significantly leaf $\mathrm{Mg}$. in the two seasons $(0.42 \& 0.40$ as compared with the control treatment $(0.25 \& 0.23)$. f- Iron (ppm): Results indicated that spraying trees with $40 \mathrm{ppm}$ selenium gave the highest significant iron (135) in the first season and in the second seasons, spraying trees with 20 ppm,40 and 160 ppm selenium gained the highest leaf Iron Content (118 \& 131\&118).

g- Zinc (ppm): Data showed that spraying trees with 40,80 and 160 ppm selenium gave the highest zinc (51\&63\&54) in the first season but in the second seasons, spraying trees with 80 ppm,160 ppm selenium gained the highest zinc $(62 \& 60)$ as compared with the control treatment (33 \& 32) in both seasons.

h- Manganese (ppm): Results indicated that spraying trees with $80 \mathrm{ppm}$ selenium gave the highest manganese (33) in the first season without insignificant differences amang all treatments Also, in the second seasons, spraying trees with $160 \mathrm{ppm}$ selenium gained the highest magnesium (30) compared with the control treatment ( $23 \& 22)$ in both seasons.

i- Selenium (ppm): Selenium data showed that spraying trees with $40 \mathrm{ppm}$ in the first season and $160 \mathrm{ppm}$ in the second season recorded higher significant values than control.

These data go in line with those reported by Ibrahim and Al-Wasfy (2014) who reported that using selenium enhanced nutritional status of $\mathrm{Va}$ lencia orange trees., Shaimaa et al (2016) who indicated that treatment of Se at $5 \mathrm{ppm}$ gave the highest leaf $\mathrm{N}, \mathrm{P}, \mathrm{K}$, and $\mathrm{Fe}$ content and the same treatment gave the lowest leaf $\mathrm{Na}, \mathrm{Cl}$ and $\mathrm{B}$ content, whereas, treatment of Se at $20 \mathrm{ppm}$ gave the highest leaf selenium content in mango trees. And Shuaimeng et al (2017). Who found that Se fertilizer can be used to increase Se content of grape, especially for European and American species, with significant effect of increasing grape nutrition quality and an effective means of lowering heavy metals. 


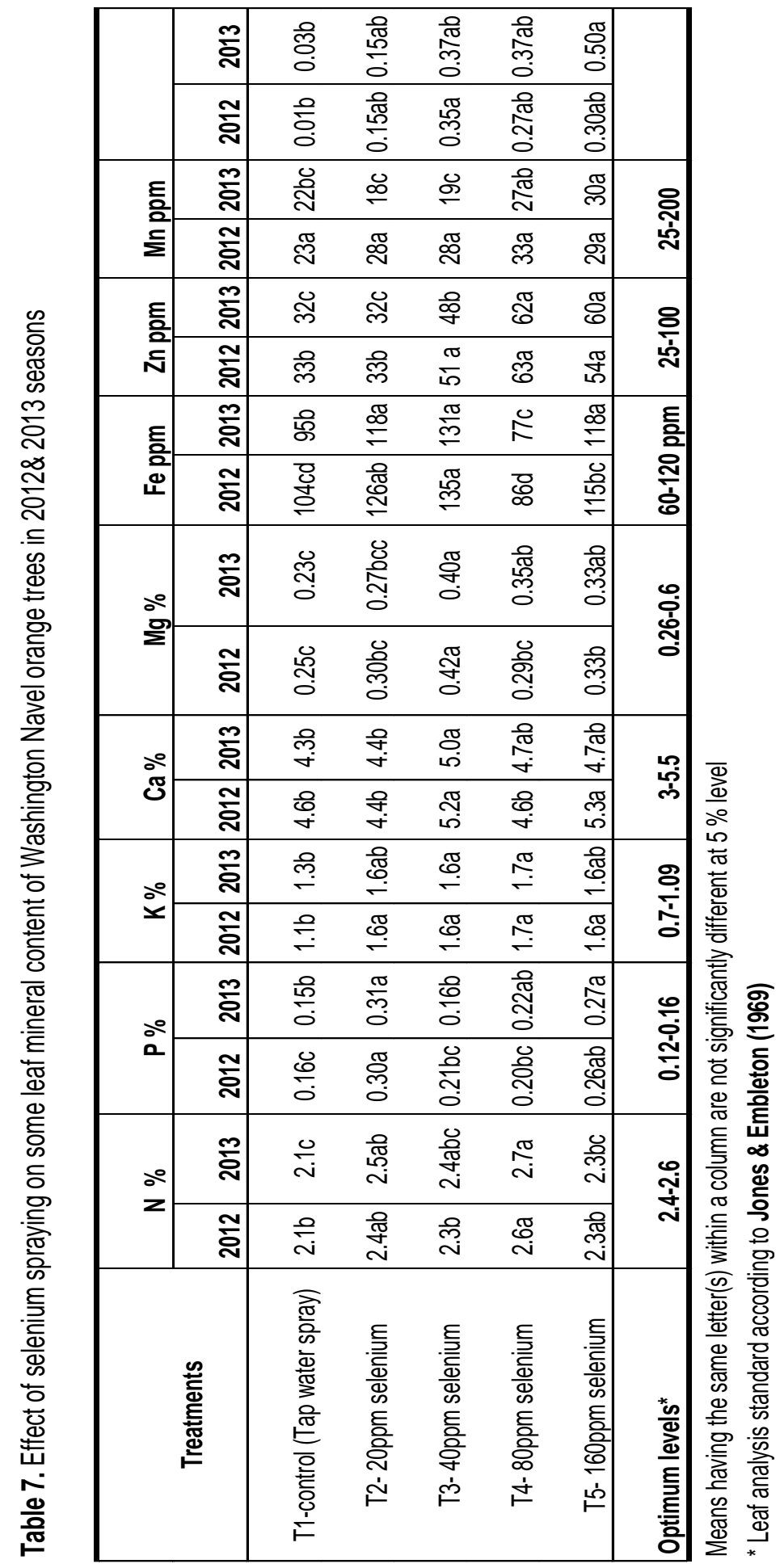


7- Fruits selenium content ppm: Data in the Table (8) recorded that spraying trees with 160 ppm selenium proved to be the highest fruits selenium content treatment in both seasons $(0.37$ \& $0.30)$ when compared with the control treatment (0.08 \& 0.07) in both seasons.

These data go in line with those reported by Shuaimeng et al (2017). Who reported that Se fertilizer can be used to increase Se content of grape.

Also, the average daily Se intake to the range considered as safe and adequate, 0.05-0.2 mg/day Food and Nutrition Board, (1980).

Table 8. Effect of selenium spraying on fruits selenium content of Washington Navel orange trees in 2012\& 2013 seasons

\begin{tabular}{|l|c|c|}
\hline \multirow{2}{*}{\multicolumn{1}{|c|}{ Treatments }} & \multicolumn{2}{c|}{ Se. ( ppm ) } \\
\cline { 2 - 3 } & 2012 & 2013 \\
& season & season \\
\hline T1-control (Tap water spray) & $0.08 \mathrm{bc}$ & $0.07 \mathrm{~b}$ \\
T2- 20ppm selenium & $0.05 \mathrm{c}$ & $0.08 \mathrm{~b}$ \\
T3- 40ppm selenium & $0.17 \mathrm{bc}$ & $0.20 \mathrm{ab}$ \\
T4- 80ppm selenium & $0.25 \mathrm{ab}$ & $0.22 \mathrm{ab}$ \\
T5- 160ppm selenium & $0.37 \mathrm{a}$ & $0.30 \mathrm{a}$ \\
\hline
\end{tabular}

Means having the same letter(s) within a column are not significantly different at $5 \%$ level

\section{8- Enzymes activity}

a- Pectinase activity $(\Delta \mathbf{n} / \mathrm{Hr})$ : Spraying trees with $80 \mathrm{ppm}$ and $160 \mathrm{ppm}$ selenium gave the highest pectinase activity $(4.0 \& 4.0)$ in the first date but in the second date, spraying trees with $80 \mathrm{ppm}$ selenium gained the highest pectinase activity (4.6). On the contrary to the lowest significant values was obtained by the control treatment $(3.1 \& 3.7)$ in both seasons.

b- Cellulase activity $(\Delta \mathrm{n} / \mathrm{Hr})$ :Spraying trees with $20 \mathrm{ppm}$ and $40 \mathrm{ppm}$ selenium proved to be the highest cellulose activity $(8.2 \& 7.9)$ in first date but in the second date, spraying trees with $20 \mathrm{ppm}$ selenium gained the highest significant cellulase activity (10.0) when compared with the control treatment (6.8\& 8.8).

These data go in line with those reported by Dayer et al (2008) Who reported that The theoretical explanation for the antioxidative effects of Se on plants is increasing the activity of the enzyme glutathione-peroxidase (GSH-Px) in seleniumtreated plants, since Se-containing GSH-Px was identified in plants and Khattab (2004) studied the metabolic and oxidative responses of selenium and the results showed that both enzymatic and non enzymatic antioxidants as well as $\mathrm{Ca}^{2+}$ played significant roles in selenate detoxification.

Table 9. Effect of selenium spraying on some enzymes activity of Washington Navel orange trees during 2013 season

\begin{tabular}{|l|c|c|c|c|}
\hline \multirow{2}{*}{ Treatments } & \multicolumn{2}{|c|}{ Pectinase activity $(\Delta \mathbf{n} / \mathbf{H r})$} & \multicolumn{2}{c|}{ Cellulase activity( $\Delta \mathbf{n} / \mathbf{H r})$} \\
\cline { 2 - 5 } & $\mathbf{1 5 / 5 / 2 0 1 3}$ & $\mathbf{1 5 / 1 2 / 2 0 1 3}$ & $\mathbf{1 5 / 5 / 2 0 1 3}$ & $\mathbf{1 5 / 1 2 / 2 0 1 3}$ \\
\hline T1-control (Tap water spray) & $3.1 \mathrm{c}$ & $3.7 \mathrm{c}$ & $6.8 \mathrm{~b}$ & $8.8 \mathrm{bc}$ \\
T2- 20ppm selenium & $3.3 \mathrm{bc}$ & $4.0 \mathrm{bc}$ & $8.2 \mathrm{a}$ & $10.0 \mathrm{a}$ \\
T3- 40ppm selenium & $3.6 \mathrm{ab}$ & $4.3 \mathrm{ab}$ & $7.9 \mathrm{a}$ & $9.1 \mathrm{~b}$ \\
T4- 80ppm selenium & $4.0 \mathrm{a}$ & $4.6 \mathrm{a}$ & $7.0 \mathrm{~b}$ & $8.1 \mathrm{c}$ \\
T5- 160ppm selenium & $4.0 \mathrm{a}$ & $4.1 \mathrm{~b}$ & $6.0 \mathrm{c}$ & $8.2 \mathrm{c}$ \\
\hline
\end{tabular}

Means having the same letter(s) within a column are not significantly different at $5 \%$ level

In conclusion, one can say that spraying Washington Navel Orange cv. trees with selenium at 40 ppm under the conditions of this study resulted in a significant increase in yield and enhanced fruit characteristics.

\section{REFERENCES}

Abeles F.B. and Takeda F. 1990. Cellulase activity and ethylene in ripening strawberry and apple fruits. Scient. Hort., 42, 269-275. 

growth, productivity and fruit quality

Ahmed F.F. and Morsy M.H. 1999. A new method for measuring leaf area in different fruit species. Minia. J. Agric. Res. \& Dev.19, 97-105.

A.O.A.C. 1995. Official methods of analysis (A.O.A.C) Pub.By official A.O.A .C chapter 4. pp. 8-44.

Brown J.D. and Lilleland D. 1946. Rapid determination of potassium and sodium in plant material and soil extract by Flame photometer. Proc. Amer. Soc. Hort. Sci. 48, 331- 346.

Chapman H.D. and Pratt P.E. 1961. Methods of Analysis for Soil, Plant and Water. Davis Agric. Sci. Pull Office Calif. Univ., pp. 220 308.

Dayer R., Fischer B.B., Eggen R.I.L. and Lemaire S.D. 2008. The peroxiredoxin and glutathione peroxidase families in Chlamydomonas reinhardtii. Genetics, 179, 41 - 57.

Duncan D.B. 1955. Multiple rang and multiple FTest. Biometrics, 11, 1-42.

Durbin M.L. and Lewis L.N. 1988. Cellulases in phaseolus vulgaris. Methods in Enzymology, 160, 342-351.

Food and Nutrition Board. 1980. Recommended Dietary allowances. $9^{\text {th }}$ ed. Washington DC, National Acdemy of Sci. 38, 290-294.

Gad El-Kareem M.R., Abdel Aal A.M.K. and Mohamed A.Y. 2014. The Synergistic Effects of Using Silicon and Selenium on Fruiting of Zaghloul Date Palm (Phoenix dectylifera L.). J. of Biological, Biomolecular, Agric. Food and Biotechnological Engineering 8(3), 259-262.

Gissel- Neilsen G., Gupta U.C., Lamand M. and Westermarck T. 1984. Selenium in soils and plants and its importance in livestock and human nutrition. Adv. Agron. 37, 398-453.

Guoliang W. and Jianbao T. 2009. Progress of fruit plants in selenium - enriched research in China. Acta. Horticulturae. 841, 599-602.

Gupta U.C., Gupta S.C. and Gupta M.D. 2000 Selenium in soils and crops, its deficiencies in livestock and humans, implication for management. Commun. Soil Sci. Plant Anal. 31, 1791-1807.

Hanson B., Garifullina G.F., Lindblom S.D., Wangeline A., Ackley A., Kramer K., Norton A.P., Lawrence C.B. and Pilon-Smits E.A.H. 2003. Selenium accumulation protects Brassica juncea from invertebrate herbivory and fungal infection. New Phytologist, 159, 461- 469.

Hartikainen M. and Xue T. 1999. The promotive effect of selenium on plant growth as triggered by W Harviolet radiation. J. of Environ. Quality, 28, 1372 - 1375.
Ibrahim H.I.M. and Al-Wasfy M.M. 2014. The promotive impact of using silicon and selenium with potassium and boron on fruiting of Valencia orange trees grown under minia region conditions. World Rural Observations 6(2), 28 -36.

Jakovljevic M., Licina V., Antic-Mladenov S. and Velickovic M. 2011. The effects of selenium application on replant soil and its content in apple leaves and fruits. Acta Hort. 477: IV Inter. Sym. on Replant Proplems P.I.

Jones W.W. and Embleton T.W. 1969. Development and current status of citrus leaf analysis as guide to fertilization in california. Proceeding First Int. Citrus Symposium, 3, 16691671.

Khattab H. 2004. Metabolic and oxidate response associated with exposure or eruca sativa rocket plant to different levels of selenium. Int. J. of Agric. and Biology., 6, 1101-1106.

M.A.L.R. 2015. Ministry of Agriculture and land Reclamation economic affairs, Egypt Agric. Di-rectorates of Governorates, 2, 284-288.

Nijjar G.S. 1985. Nutrition of fruit trees Mrs. Usha Raji Kumar, Kilyani, New Delhi, India, pp. 10-20.

Nowak- Barbara H. 2008. Effect of selenium on selected macronutrients in maize plants. J. Elemental. 13(4), 513 - 519.

Piper C.S. 1958. Soil and Plant Analysis. Int. Sci. Pub., Inc. New York, USA, pp. 360-370.

Pregl F. 1945. Quantitative organic micro-analysis. $4^{\text {th }}$ Ed. J.A. Churchill, Ltd, London, 238 p.

Qiu Hui H., Juan X. and Genxin P. 2001. Effect of selenium spraying on green tea quality. $\mathbf{J}$. of the Sci. of Food and Agric. 2001.81: 14, 1387-1390.

Rayman M.P. 2002. The argument for increasing selenium intake. Proceeding of the Nutrition Society, 61, 203-215.

Seppanen M., Turakainen M. and Harikainen $\mathbf{H}$. 2003. Selenium effects on oxidative stress in potato. Plant Sci., 165, 311-319.

Shaimaa M., Abou-Rawash M., El-Wakeel H., and Omaima M. El-sayed 2016. Effect of magnetite soil application and selenium foliar spray on adult mango trees grown under drip irrigation system in sandy soil. J. Biol. Chem. Environ. Sci. 11(3), 585-604.

Shuaimeng Z., Yinli L., Dekai G., Xiaojuan A., and Fanchao K. 2017. Spraying foliar selenium fertilizer on quality of table grape (Vitis vinifera L.) from different source varieties.Scientia Horticulturae 218, 87-94. 
Sima P. and Gissel-Neilsen G. 1985. Spraying crops with selenium. Acta Agric. Sec. 35, 161 - 164.

Snedecor G.A. and Cochran W.G. 1980. Statistical Methods. Oxford and J.B.H. Bub Com. ( $7^{\text {th }}$ Ed.), $507 \mathrm{p}$.

Turakainen M., Hartikainen $H$. and Sepanen M.M. 2004. Effect of selenium treatments on potato (Solatium luberosum L.) growth concentration of soluble sugars and starch. J. of Agric. and Food Chem., 52, 5378 - 5382.

Turakainen M., Hartikainen H., Ekholm P. and Seppanen M.M. 2006. Distribution of selenium in different biochemical fractions and raw darkening degree of potato (Solanum luberosum L.) tubers supplemented with selenate. J. of Agric. and Food Chem., 54, 8617 - 8622.

Wilde S.A., Corey R.B., Layer J.G. and Voigt G.K. 1985. Soils and Plant Analysis for Tree Culture. ( $3^{\text {rd }}$ Ed.). Oxford and IBH Publishing Co., New Delhi, India, pp. 529 - 546.

Ya-o-Xiang P. and Zheng - Fo. C. 2007. Physiological function of selenium and development utilization of Rich selenium fruits research of Agric. Modirination, pp. 341-566.

Zhang HaiYing, Han Tao, Tian Lei and Wang YouNian 2011. Effects of cadmium and lead accumulation in strawberry growing period by spraying Se-fertilizer to leaves. Acta Horticulturae Sinica 38(3), 409-416. 
مجلة اتحاد الجامعات العربية للعلوم الزراعية ، جامعة عين شمس ، القاهرة ، مصر

مجلد(26)، عدد(2D)، عدد خاص ، 2019

Website: http://strategy-plan.asu.edu.eg/AUJASCI/

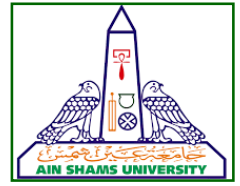

2323

تأثير رش أثجار البرتقال بسره بالسلينيوم علي النمو الخضري و الانتاجيه وجوده الثمار

$168]$

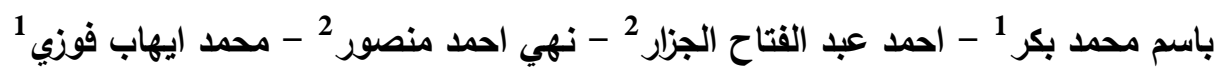

1- قسم البساتين - كليه الزراعه - جامعه عين شمس - صندوق بريد 68 - حدائق شبرا 11241 - القاهره - مصر

2- قسم الفاكهه - المركز القومي للبحوث - الدقي - الجيزه - مصر عاعه

*Corresponding author: basemlife@yahoo.com

Received 18 March, 2018

Accepted 30 July, 2018

وأوضحت النتائج ان السلينيوم له تأثنير معنوي علي

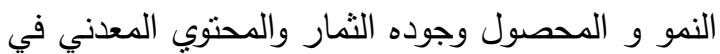

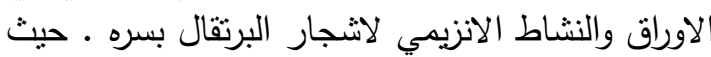

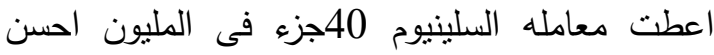

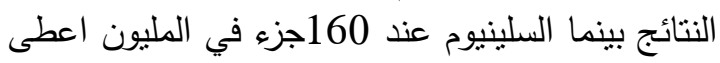

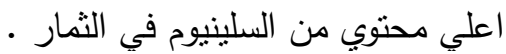

الكلمات الدالة: البرتقال بسره، سلينيوم،المحصول، جوده الثمار ، المحتوي المعدني للاوراق الهات

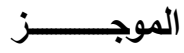

أجريت هذه الدراسة خلال عامى 2012، 2013

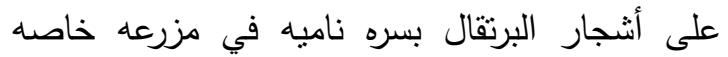

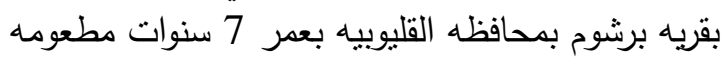

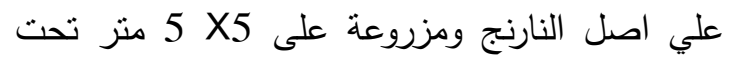
نظام الرى بالغمر • وتهدف هذه التجربة الي دراسه تأثنير

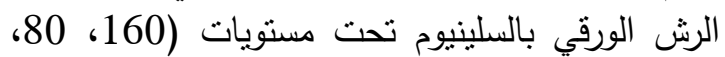

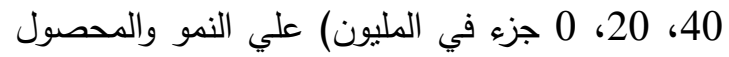
وجوده الثمار والمحتوى المعدني في الاوراق والني النشاط ولني الانزيمى وذلك لاثجار البرتقال بسره. 